\title{
Pendidikan Islam Multikultural Upaya Menumbuhkan Kesadaran Multikultural
}

\begin{abstract}
Abstrac
Islam moderate, is a typical Indonesian Islam that has been tested by history, and became the inspiration of international Muslims. Islam and Indonesian Muslims continue to find their momentum as a religion that promotes moderate, inclusive, humanist, tolerant and peaceful attitudes, isathiyah Islam is a typical Indonesian Islam. But lately, the uniqueness began to shift. In facts about the conflict and violence perpetrated by individuals and groups in the name of religion even under the pretext of defending religion have undermined diversity and tolerance itself
\end{abstract}

Keywords: Islamic education, Multicultural, Inclusif, Tolerant

\begin{abstract}
Abstrak
Islam moderat, merupakan Islam khas Indonesia yang sudah teruji oleh sejarah, dan menjadi inspirasi muslim internasional. Islam dan muslim Indonesia tetap menemukan momentumnya sebagai agama yang mengedepankan sikap-sikap moderat, inklusif, humanis, toleran dan damai, Islam wasathiyah adalah Islam khas Indonesia. Namun akhir-akhir ini, keunikan mulai bergeser. Sejumlah fakta tentang konflik dan kekerasan yang dilakukan oleh individu maupun kelompok dengan mengatasnamakan agama bahkan dengan dalih membela agama telah merusak kebhinekaan dan toleransi itu sendiri.
\end{abstract}

Kata Kunci: Pendidikan Agama Islam, Multikultural, Inklusif, Toleran

Zainal Arifin

Dosen PAI STAI Miftahul Ula, Ketua LP Ma'arif NU Nganjuk

Zainalnisa@gmail.com 


\section{Zainal Arifin}

\section{A. Islam dan Multikulturalisme}

Dalam tinjauan kebahasaan, multikulturalisme terdiri dari kata multi dan cultural. Multi berarti plural, sedang cultural berarti kebudayaan, dan isme yang berarti kepercayaan atau aliran. Multikulturalisme dalam pengertian sederhana adalah paham atau aliran tentang pluralitas (keragaman) budaya. Pada mulanya multikulturalisme adalah filosofi atau pandangan hidup yang terkadang menjelma sebagai kekuatan ideology yang menghendaki adanya persatuan dari berbagai kelompok kebudayaan dengan hak dan status social politik yang sama dalam masyarakat modern. Istilah multikulturalisme sering digunakan untuk menggambarkan kesatuan berbagai etnis masyarakat yang berbeda. ${ }^{1}$

Sebagai sebuah ideology, multikulturalisme muncul di tengah dinamika yang berkembang dalam masyarakat barat. Beberapa kejadian yang bermuara pada segregasi dan terabaikannya hak-hak individu maupun kelompok telah turut andil dalam lahirnya gerakan multicultural yang di dalamnya juga terdapat pendidikan multicultural. Menurut Parekh terdapat tiga hal penting dalam multikulturalisme, yaitu (1) berkenaan dengan budaya; (2) merujuk pada keragaman yang ada; (3) berkenaan dengan tindakan spesifik pada respons terhadap keragaman tersebut.

Namun, sebagai sebuah nilai-nilai yang ditanamkan dalam masyarakat, multikulturalisme telah dikenal dalam khazanah Islam awal. Hal itu berlanjut dalam diskursus-diskursus ke-Islaman hingga dewasa ini.

Nilai-nilai multicultural dalam Islam sebenarnya telah mengakar erat. Zuhaily, dalam tafsir al-Munir mengutip hadis riwayat Muslim dan Ibnu Majah dari Abu Hurairah ra. Rasulullah SAW. Bersabda: "sesungguhnya Allah tidak melihat kepada warnamu dan harta kekayaannmu tetapi melihat kepada hati dan amal perbuatanmu”. Dalam hadis yang lain, atThabrany, meriwayatkan hadis dari dari Abu Malik al-Asy'ary, Rasulullah SAW. Bersabda:

${ }^{1}$ Yaya Suryana \& H.A Rusdiana. 2015. Pedidikan Multikultural: Suatu Upaya Penguatan Jatidiri Bangsa: Konsep, Prinsip, Implementasi. Bandung: Pustaka Setia, Hlm. 99-102 


\section{Pendidikan Islam Multikultural}

"sesungguhnya Allah tidak melihat kepada kedudukanmu, juga tidak melihat nasabmu, juga tidak melihat ragamu, dan juga tidak melihat harta kekayaanmu, tetapi melihat kepada hatimu. Maka apabila dia mempunyai hati yang baik, Allah akan menyayanginya. Kalian semua adalah anak Adam, dan yang paling dicintai Allah adalah yang paling bertakwa kepadanya".

Hadits-hadits yang dikutip di atas memberikan pesan yang teramat jelas bagi manusia agar kehidupan berjalan dalam suasana saling menghormati, meskipun secara alamiah (sunnatullah) terdapat perbedaanperbedaan etnis, budaya, keyakinan, kedudukan dan perbedaan-perbedaan lainnya. Keluarga Rasulullah sendiri merupakan tipe keluarga dengan nuansa multikultural yang kental. Rasulullah tidak hanya memperistri wanita dari ras Arab saja, tetapi juga menikahi wanita dari ras lain. Diantara istri Rasulullah ada yang berdarah Yahudi. Shafia binti Huyay adalah keturunan bangsawan Yahudi yang kemudian memeluk Islam. Selanjutnya ada Maria binti Sam'un, wanita berdarah Qibthi yang berasal dari Mesir. Istri-istri Rasulullah tersebut setia mendampingi hingga beliau wafat. Disamping itu terdapat banyak sekali orang-orang yang dekat dengan Rasulullah. ${ }^{2}$ Selain para istri, beliau juga memiliki pembantu-pembantu yang berasal dari latar belakang suku, budaya, bahasa, serta warna kulit yang berbeda-beda

Ketika periode Madinah, dalam rentan waktu yang tidak terlalu lama, Rasulullah SAW. Berhasil mempersatukan kelompok masyarakat dan kabilah yang berada di Madinah dan sekitarnya. Diantara mereka terdapat tradisi dan agama yang berbeda-beda yang kemudian disatukan dalam satu "kontrak politik" untuk menjalani kehidupan yang rukun, damai, saling menghormati dan menjaga keamanan madinah di tengah keragaman baik etnis maupun agama. Tetapi di lain sisi, setiap anggota masyarakat mendapat hak dan kebebasannya dalam menjalankan tradisi dan praktik keagamaan. Kontrak politik itu kemudian disebut juga dengan "mitsaq

\footnotetext{
${ }^{2}$ Muhammad Tholhah Hasan. Pendidikan Multikultural sebagai Opsi Penanggulangan Radikalisme. Malang: Lembaga Penerbitan Universitas Islam Malang, 2016. Hlm.37
} 
madinah" atau Piagam Madinah yang harus dipatuhi bersama. Diantara butir-butir piagam madinah, antara lain, di antara mereka harus saling tolong-menolong; kaum Muslim dan Kaum Yahudi menyediakan dana keamanan bersama; penganut Muslim dan Yahudi bebas melakukan keagiatan-kegiatan keagamaan tanpa saling mengganggu satu dengan lainnya; masing-masing kelompok menjaga kejujuran dan loyalitas dalam kehidupan bersama; apabila terjadi sengketa dan perselisihan, maka akan diadukan masalahnya kepada Rasulullah yang akan memberi putusan dengan adil ${ }^{3}$.

Selain hadis-hadis dan pengalaman yang terjadi pada masa Rasulullah yang menyiratkan pesan yang kuat tentang tatanan kehidupan damai dalam bingkai multikultural, terdapat juga ayat al-Qur'an sesuai dengan konsep multikulturalisme. Sebuah ayat yang mengatur tatakrama pergaulan dengan sesama manusia. Ayat inilah yang merupakan prinsip dasar Islam dalam mengatur etika pergaulan antar sesama manusia, tanpa dilandasi kecurigaan akibat perbedaan keyakinan. Ayat tersebut terdapat dalam surah al-Hujurat ayat 13 .

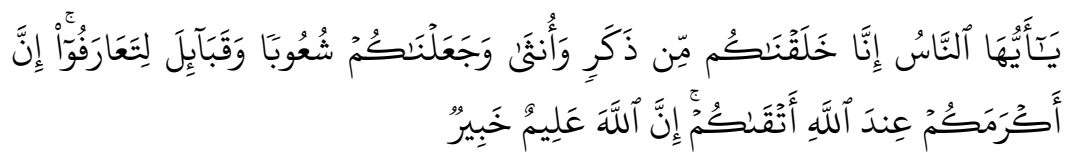

"Hai manusia, sesungguhnya Kami menciptakan kamu dari seorang laki-laki dan seorang perempuan serta menjadikan kamu berbangsa-bangsa, juga bersuku-suku supaya kamu saling mengenal. Sesungguhnya yang paling mulia diantara kamu di sisi Allah ialah yang paling bertakwa diantara kamu. Sesungguhnya Allah Maha Mengetahui lagi Maha Mengenal".

Terdapat beberapa versi terkait dengan sebab turunnya ayat tersebut. Diantaranya adalah riwayat dari Abu Daud yang menyatakan bahwa ayat ini turun berkenaan dengan Abu Hind yang pekerjaan sehari-harinya adalah sebagai pembekam. Nabi meminta kepada Bani Bayadhah agar menikahkan salah seorang putrid mereka dengan Abu Hind, tetapi mereka enggan

${ }^{3}$ Ibid, Hlm 65 


\section{Pendidikan Islam Multikultural}

dengan alasan tidak layak mereka menikahkan putri mereka dengannya yang merupakan bekas budak. Sikap ini kemudian dikecam oleh al-Qur'an dengan menegaskan bahwa kemuliaan di sisi Allah adalah karena ketakwaan bukan karena garis keturunan atau kebangsawanan. Selain itu ada juga yang meriwayatkan bahwa Usaid Ibn Abi al-Ish berkomentar ketika mendengar Bilal mengumandangkan adzan di Ka'bah. Komentarnya: “Alhamdulillah, ayahku wafat sebelum melihat kejadian ini. Ada lagi yang berkomentar: "apakah Muhammad tidak menemukan selain burung gagak ini untuk beradzan". 4

Dalam ajaran Islam, nilai-nilai universal tentang kemanusiaan, persamaan hak, pengakuan keragaman budaya dan kemajemukan dijunjung tinggi. Multicultural dalam pandangan Islam adalah sunnatullah yang akan tetap ada dan tidak berubah. Sedangkan sunnatullah bagi penganut Islam adalah keniscayaan yang tak mungkin bisa diingkari. Setiap insan akan menghadapi fakta kemajemukan di manapun ia hidup dan dalam hal apapun. Atas dasar kenyataan ini, dapat disimpulkan bahwa ajaran Islam sangat menghargai masyarakat multicultural, karena dalam Islam dengan tegas dinyatakan bahwa perbedaan setiap individu tidak boleh dijadikan alasan untuk berpecah belah.

Islam hadir di tengah-tengah masyarakat untuk mengajarkan hidup bersama saling menghormati di antara anggota masyarakat yang beragam. Dalam kehidupan masyarakat multicultural kehidupan menjadi sangat dinamis karena terdapat kerja sama sekaligus kompetisi yang sehat dan terbuka dari masing-masing elemen untuk berbuat yang terbaik menuju kemajuan dan kemaslahatan bersama-sama. Dalam Alquran, kita disuguhi ayat-ayat yang menggunakan kata dasar "adada” untuk menggambarkan suatu ragam entitas, banyak, berbilang, majemuk dan lebih dari satu. "adada" terdapat dalam surat al-Jin ayat 24, kata "ma'dudat" dalam surat al-Baqarah ayat 27,120, 183, dan 204. Kata “ma'dudah” dalam surat Hud

\footnotetext{
${ }^{4}$ Muhammad Qurais Shihab. Tafsir al-Mishbah: Pesan, Kesan, dan Keserasian Al-quran. Vol XIII Jakarta: Lentera hati. 2002, Hlm 206
} 


\section{Zainal Arifin}

ayat 87 dan surat Yusuf ayat yang ke-20. Dari aspek kebahasaan, kata "adada" mempunyai makna menghitung. Dari kata "adada" pula terdapat akar kata yang mengandung makna bernuansa pluralitas atau kemajemukan $^{5}$

Dalam alam semesta ini, seluruh wujud selain Allah terdiri dari dualitas, pluralitas,tersusun dari elemen-elemen yang berbeda-beda. Bukanlah suatu hal yang sulit untuk menemukan fenomena multicultural dalam Alquran. Sebagaimana keberagaman ciptaan Allah dalam Surat arRum ayat 22:

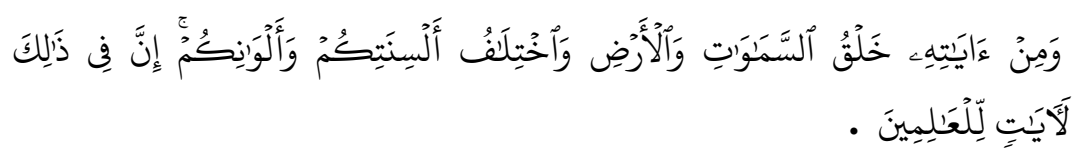

"Dan di antara tanda-tanda kekuasaan-Nya ialah menciptakan langit dan bumi dan berlain-lainan bahasamu dan warna kulitmu. Sesungguhnya pada yang demikan itu benar-benar terdapat tandatanda bagi orang-orang yang mengetahui. (Q.S. ar-Rum: 22).

Kemudian fenomena multicultural yang lain, dalam Alquran juga disinggung masalah kebangsaan dan kesukuan yang berimplikasi pada tatanan masyarakat yang berbeda. Perbedaan yang ada menurut Alquran haruslah disatukan dalam rangka membangun tatanan masyarakat yang terdiri dari perbedaan. Untuk itu diperlukan sebuah kondisi saling mengenal (ta'aruf). Berkenaan dengan hal ini surat al-Hujurat ayat 13 menjelaskan:

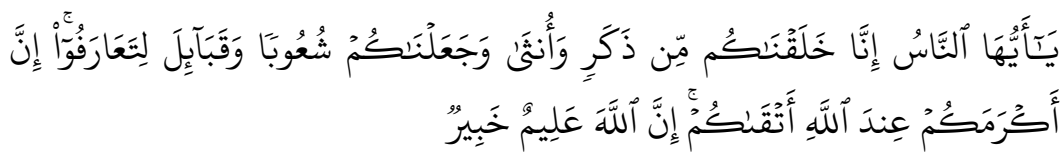

"Hai manusia, sesungguhnya Kami menciptakan kamu dari seorang laki-laki dan seorang perempuan dan menjadikan kamu berbangsa-bangsa dan bersuku-suku supaya kamu saling kenalmengenal. Sesungguhnya orang yang paling mulia diantara kamu disisi Allah ialah orang yang paling takwa diantara kamu. Sesungguhnya Allah Maha Mengetahui lagi Maha Mengenal".(Q.S. al-Hujurat: 13)

${ }^{5}$ Ema Erfina. Pendidikan Islam Multikultural Berbasis Kearifan Lokal: Studi Lokasi Pondok Pesantren Babussalam Mojoagung Jombang dan Pondok Pesantren Mamba'ul Qur'an Mojokerto. Universitas Islam Malang: Disertasi, 2017, Hlm 83-84 


\section{Pendidikan Islam Multikultural}

Adanya perbedaan dan ciri khas peradaban manusia adalah sunnatullah yang tidak bisa dihindari dan direkayasa. Adanya perbedaan dalam masyarakat juga fenomena multicultural yang menjadikan suatu masyarakat untuk tergerak berlomba-lomba menghasilkan karya terbaiknya demi mewujudkan masyarakat multicultural. Dalam Alquran ditandaskan tentang kehendak (iradah) Allah menciptakan manusia yang beragam. Seandainya Allah berkehendak untuk menciptakan manusia satu umat saja (monokultural) tentu dengan kuasaNya yang meliputi segala hal, bukanlah suatu hal yang mustahil. Sebagaimana dijelaskan dalam Surat Hud ayat 118:

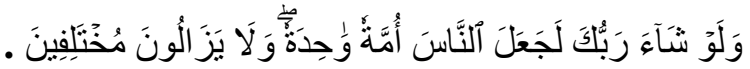

"Jikalau Tuhanmu menghendaki, tentu Dia menjadikan manusia umat yang satu, tetapi mereka senantiasa berselisih pendapat” (Q.S. Hud: 118).

Dengan kandungan yang terdapat persamaan, dalam Surat Yunus juga dijelaskan:

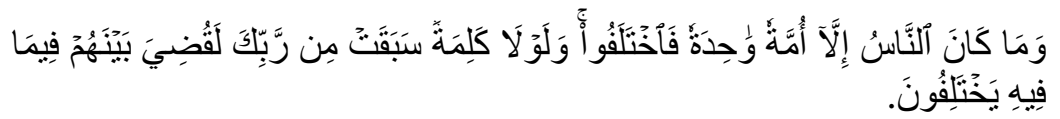

"Manusia dahulunya hanyalah satu umat, kemudian mereka berselisih. Kalau tidaklah karena suatu ketetapan yang telah ada dari Tuhanmu dahulu, pastilah telah diberi keputusan di antara mereka, tentang apa yang mereka perselisihkan itu”. (Q.S. Yunus: 19)

Fenomena multicultural juga terdapat dalam Surat al_maidah ayat 48:

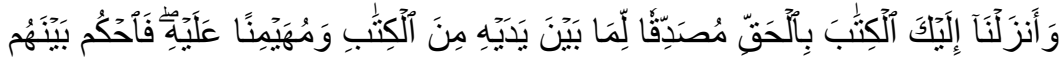

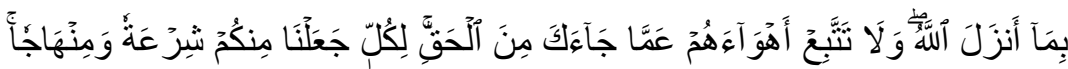

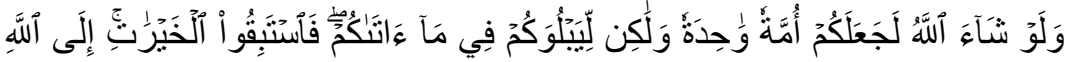

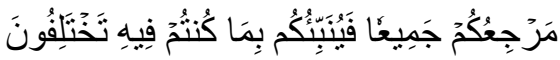

"Dan Kami telah turunkan kepadamu Al Quran dengan membawa kebenaran, membenarkan apa yang sebelumnya, yaitu kitabkitab (yang diturunkan sebelumnya) dan batu ujian terhadap kitab-kitab yang lain itu; maka putuskanlah perkara mereka menurut apa yang Allah turunkan dan janganlah kamu mengikuti hawa nafsu mereka 
dengan meninggalkan kebenaran yang telah datang kepadamu. Untuk tiap-tiap umat diantara kamu, Kami berikan aturan dan jalan yang terang. Sekiranya Allah menghendaki, niscaya kamu dijadikan-Nya satu umat (saja), tetapi Allah hendak menguji kamu terhadap pemberianNya kepadamu, maka berlomba-lombalah berbuat kebajikan. Hanya kepada Allah-lah kembali kamu semuanya, lalu diberitahukan-Nya kepadamu apa yang telah kamu perselisihkan itu" (Q.S. al-Maidah: 48).

Ayat di atas menyinggung tentang keragaman syariat agama-agama, terlebih agama samawi. Dalam kerangka keragaman syariat agama samawi terdapat pernyataan Alquran bahwa pemeluk agama samawi-walaupun mempunyai syariat yang berbeda-beda - tetap mempunyai kemungkinan untuk selamat dan mendapat pahala dari Tuhan jika mereka berpegang pada sikap iman kepada Allah, iman kepada akhirat, kebangkita, perhitungan amal (hisab), pembalasan amal baik dan buruk dan beramal sholeh ketika hidup di dunia. Hal ini dijelaskan dalam Surat al-Baqarah ayat 62:

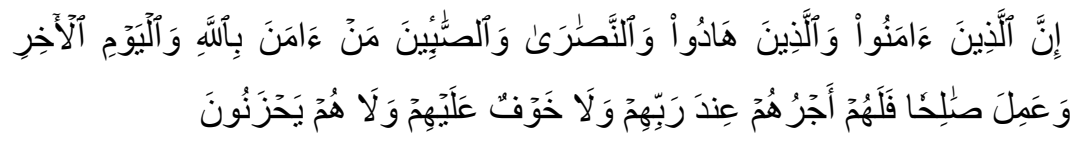

"Sesungguhnya orang-orang mukmin, orang-orang Yahudi, orangorang Nasrani dan orang-orang Shabiin, siapa saja diantara mereka yang benar-benar beriman kepada Allah, hari kemudian dan beramal saleh, mereka akan menerima pahala dari Tuhan mereka, tidak ada kekhawatiran kepada mereka, dan tidak (pula) mereka bersedih hati" (Q.S. al-Baqarah: $62)$.

\section{B. Pendidikan Multikultural}

Beberapa pakar memberikan pendapatnya tentang definisi pendidikan multikultural. Banks mengatakan bahwa pendidikan multikultural adalah: “...is a concept, a frame work, a way of thinking, a philosophical viewpoint, a value orientation, and a set of educational nedds of culturally diverse student populations". Pendidikan multikultural adalah konsep, ide atau falsafah sebagai suatu rangkaian kepercayaan (set of believe) dan penjelasan yang mengakui dan menilai pentingnya keragaman budaya dan etnis dalam membentuk gaya hidup, pengalaman sosial, identitas pribadi, kesempatan-kesempatan pendidikan dari individu, 


\section{Pendidikan Islam Multikultural}

kelompok maupun Negara. ${ }^{6}$ Oleh karena itu pendidikan multikultural ditujukan untuk mempersiapkan peserta didik dengan sejumlah sikap dan keterampilan yang diperlukan dalam lingkungan budaya etnik mereka, budaya nasional dan antar budaya etnik lainnya.

Pendidikan multikultural bukanlah sebuah entitas yang berdiri sendiri. Banks menjelaskan bahwa terdapat beberapa dimensi yang saling berkaitan antara satu dengan lainnya:

1. Content Integration. Adalah upaya untuk mengintegrasikan berbagai budaya dan kelompok untuk mengilustrasikan konsep dasar, generalisasi dan teori dalam mata pelajaran. Integrasi isi berkaitan dengan sejauh mana guru menggunakan contoh dan konten dari berbagai budaya dan kelompok untuk menggambarkan konsep kunci, prinsip, generalisasi, dan teori di wilayah topik mereka mengenai disiplin tertentu.

2. The Knowledge Construction Process. Pembelajaran yang dilakukan diharapkan menjadikan peserta didik memahami implikasi budaya ke dalam sebuah mata pelajaran. Pendidik mengajak peserta didik untuk memahami implikasi budaya ke dalam sebuah mata pelajaran, dalam hal ini guru dapat membantu siswa "memahami bagaimana pengetahuan diciptakan dan bagaimana hal itu dipengaruhi oleh kedudukan ras, etnis, dan kelas sosial individu dan kelompok.

3. An Equity Paedagogy. Menyesuaikan metode pengajaran dengan cara siswa belajar dalam rangka memfasilitasi prestasi akademik siswa yang beragam baik dari segi ras, budaya (culture) ataupun sosial. Ini ada ketika guru mengubah pengajaran mereka dalam cara yang memfasilitasi pencapaian akademik siswa dari kelompok ras, budaya, dan sosial-kelas yang beragam. Ini termasuk dengan berbagai gaya mengajar yang konsisten dengan gaya pembelajaran yang luas dan bervariasi dalam berbagai kelompok budaya \& etnik. Merujuk pada

\footnotetext{
${ }^{6}$ James A. Banks \& John Ambrosio. 2001. “Multikultural Education” dalam Handbook of Research on Multikultural Education San Fransisco: Jossey-Bass, Hlm. 89
} 


\section{Zainal Arifin}

penggunaan teknik pengajaran yang mempermudah pengajaran kepada siswa dari kelompok etnis dan kelas sosial yang berbeda. Sehingga pendidikan multikultural harus diselenggarakan dengan menyesuaikan metode pembelajaran dengan cara belajar peserta didik, hal ini dilakukan dalam rangka memfasilitasi prestasi akademik siswa yang beragam mulai dari ras, budaya maupun social. Sehingga pedagogi kesetaraan ada ketika guru mengubah pengajaran mereka ke cara yang akan memfasilitasi prestasi akademis dari siswa dari berbagai kelompok ras, budaya, dan kelas sosial. Termasuk dalam pedagogi ini adalah penggunaan beragam gaya mengajar yang konsisten dengan banyaknya gaya belajar di dalam berbagai kelompok budaya dan ras.

4. Prejudice Reduction. Mengidentifikasi karakteristik ras siswa dan menentukan metode pengajaran mereka. Kemudian melatih kelompok untuk berpartisipasi dalam kegiatan, semisal olah raga, berinteraksi dengan seluruh staff dan siswa yang berbeda etnis dan ras dalam upaya menciptakan budaya akademik yang toleran dan inklusif. Dimensi ini fokus terhadap karakteristik sikap rasial siswa dan bagaimana mereka dapat dimodifikasi dengan metode dan materi pengajaran. Pengurangan prasangka merupakan sasaran penting pendidikan multikultural. Pengurangan prasangka meliputi pengembangan hubungan positif dikalangan siswa dari latar belakang etnis yang berbeda, maupun pengembangan sikap yang lebih demokratis dan toleransi terhadap orang lain ${ }^{7}$.

Azra berpendapat bahwa pendidikan multicultural adalah pengganti dari pendidikan intercultural. Pendidikan multicultural menurut azra diharapkan dapat menumbuhkan sikap peduli dan mau mengerti atau adanya politik pengakuan terhadap kebudayaan kelompok manusia, seperti toleransi, perbedaan etno-kultural, dan agama, diskriminasi, HAM,

${ }^{7}$ Ibid, Hlm. 103-105 


\section{Pendidikan Islam Multikultural}

demokrasi dan pluralitas, kemanusiaan universal, serta subyek lain yang relevan.

Sedangkan Aly mengkategorikan definisi pendidikan multikultural menjadi dua kelompok. Pertama, definisi yang dibangun berdasarkan prinsip demokrasi, kesetaraan dan keadilan. Kedua, definisi yang dibangun berdasarkan sikap sosial, yaitu pengakuan, penerimaan dan penghargaan. Kategori pertama, menurut Aly, dengan mengutip pendapat dari James Banks, bahwa pendidikan multikultural adalah "konsep pendidikan yang memberikan kesempatan yang sama kepada semua peserta didik-tanpa memandang gender dan kelas sosial, etnis, ras, agama dan karakteristik cultural mereka - untuk belajar di dalam kelas. Menurut Aly, definisi yang dilontarkan Banks ini masih terkesan sangat umum. Semua aspek pendidikan terangkum dalam pengertian pendidikan multikultural, Banks tidak membatasi pendidikan multikultural hanya dalam satu aspek saja. pendidikan multikultural seharusnya mencakup semua aspek dalam pendidikan seperti; pendidik, materi, metode, kurikulum, dan lain sebagainya. Dengan begitu keseimpulan yang diambil adalah apapaun latar belakang peserta didik yang terdiri dari kelas sosial, ras, etnis, agama yang berbeda-beda ${ }^{8}$.

Sementara kategori yang kedua, yaitu penerimaan dan penghargaan, dengan mengutip pendapat Okada dan Wilson, Aly menjelaskan bahwa pendidikan multikultural adalah "pendidikan yang membantu para peserta didik untuk mengembangkan kemampuan mengenal, menerima, menghargai, dan merayakan keragaman cultural”. Okada mendefinisikannya dalam arti yang luas, pendidikan multikultural tidak terbatas pada salah satu aspek dari pendidikan tetapi mencakup semua aspek pendidikan — seperti aspek pendidik, peserta didik tujuan materi, kurikulum, metode dan evaluasi. Pendidikan dalam hal ini, haruslah diarahkan untuk mengembangkan peserta didik dalam rangka mengenal,

${ }^{8}$ Abdullah Aly. Pendidikan Islam Multikultural di Pondok Pesantren: Telaah terhadap Kurikulum di Pondok Pesantren Modern Islam Assalam Surakarta. Yogyakarta: Pustaka Pelajar, 2011., Hlm. 
menerima, dan menghargai keragaman cultural di sekolah tempat ia belajar. ${ }^{9}$

Lebih lanjut Aly menyimpulkan, bahwa terdapat tiga karakteristik dalam pendidikan multikultural. Pertama, pendidikan multikultural berprinsip pada demokrasi, kesetaraan dan keadilan. Kedua, pendidikan multikultural berorientasi pada kemanusiaan, kebersamaan dan kedamaian. Ketiga, pendidikan multikultural mengembangkan sikap mengakui, menerima dan menghargai keragaman budaya ${ }^{10}$.

\section{Pendidiakn Islam Multikultural}

Pendidikan agama Islam Multikultural adalah pendidikan yang menempatkan multicultural sebagai salah satu visi pendidikan dengan karakter utama yang bersifat inklusif, egaliter, demokratis, dan humanis, namun tetap kokoh pada nilai-nilai spiritual dan keyakinan yang berdasarkan al-Qur'an dan hadis. Dengan demikian, inti atau substansi dari pendidikan Islam multicultural adalah kesediaan menerima orang atau kelompok lain secara sama sebagai kesatuan, tanpa memperdulikan perbedaan budaya, etnik, gender, bahasa, agama dan sebagainya. Dalam konteks inilah, ada perbedaan yang signifikan antara multiklultural dan pluralisme. Jika pluralisme hanya atau sekedar mempresentasikan kemajemukan, aka multicultural memberikan penegasan bahwa dengan perbedaan itu kita sama di ruang publik.

Meskipun isu sentralnya dalam pendidikan Islam Multikultural pengakuan keragaman, namun hal itu bukan berarti kita harus menyelenggarakan pendidikan yang peserta didiknya terdiri dari beberapa suku dan budaya, menggunakan beragam bahasa, atau mengajarkan beragam agama, tetapi memberikan arahan dan pedoman serta kesadaran atau pengetahuan bahwa sebagai masyarakat yang plural kita harus sadar akan keberagaman kita dalam konteks etnik, budaya, agama, bahasa, wilayah, dan sebagainya. Namun seandainya hal itu bisa terlaksana atau 


\section{Pendidikan Islam Multikultural}

terwujud, maka hal itu jauh lebih baik. Tetapu kenyataan, kita hanya harus tetap bisa saling menolong, membantu, hidup rukun, damai dan harmoni.

\section{Menumbuhkan Multikultural di Masyarakat melalui Pendidikan}

Menurut Hasan masyarakat multicultural adalah suatu masyarakat yang di dalamnya terdiri dari beberapa macam komunitas budaya dengan segala kelebihannya, dengan sedikit perbedaan konsepsi mengenai dunia, suatu system arti, nilai, bentuk organisasi social, sejarah, adat serta kebiasaan $^{11}$. Sedangkan Cikusin berpendapat bahwa multicultural adalah pengakuan atas martabat manusia yang hidup dalam komunitasnya dengan kebudayaan masing-masing yang unik. $^{12}$ Sedangkan masyarakat multicultural adalah masyarakat yang terdiri dari dua atau lebih komunitas atau kelompok yang secara cultural dan ekonomi terpisah-pisah, secara struktur kelembagaan berbeda satu sama lain.

Sebagai sebuah paham, multikulturalisme relatif baru. Paham ini muncul pada decade 70-an di Amerika, Kanada, Inggris dan Australia. Multikulturalisme digunakan oleh pemerintah untuk mengatur pluralitas etnik dalam menentukan kebijakan public. Pemerintah Kanada, pada tahun 1965, mengeluarkan kebijakan multikulturalisme setelah mempertimbangkan pesatnya arus imigrasi dan mengacu pada undangundang yang berkaitan dengan keyakinan yang di dalamnya memberikan perhatian terhadap nilai persamaan, toleransi dan inklusivisme terhadap kelompok pendatang dari berbagai etnis

Tilaar menjelaskan bahwa pengakuan atas pluralitas budaya tak bisa dipisahkan dari nilai-nilai yang terkandung dalam multikulturalisme. Tilaar memberikan penjelasan bahwa Pluralisme budaya bukanlah suatu yang tiba-tiba ada (given), tetapi merupakan suatu proses internalisasi nilai-nilai di dalam suatu komunitas. Lebih lanjut, Tilaar memberikan catatan "tidak mengherankan apabila John Dewey, tokoh politik demokrasi dan pendidikan demokrasi, telah melahirkan karya besarnya mengenai

\footnotetext{
${ }^{11}$ Muhammad Tholhah Hasan. Op Cit. Hlm.11

${ }^{12}$ Yaqub Cikusin. Perkembangan Masyarakat Multikultural. Malang: Unisma, 2016, Hlm 2
} 
hubungan antara demokrasi dan pendidikan" (Tilaar, 2004: 179) ${ }^{13}$. Pada tahap berikutnya, multikulturalisme kemudian mengalami perpaduan dengan pendidikan. Pada decade 1960-an muncullah gagasan tentang pendidikan multikultural di Amerika Serikat dan negara-negara Barat.

Pendidikan multikutural yang diterapkan melalui lembaga pendidikan formal, diharapkan dapat ditanamkan nilai-nilai saling menghargai dan toleransi terhadap segala bentuk keberagaman yang dimiliki oleh manusia kepada peserta didik. Internalisasi pendidikan multikultural dalam pendidikan formal belum banyak dilakukan. Karena memang hal tersebut secara eksplisit belum disebutkan dalam standar nasional pendidikan yang harus dilaksanakan lembaga pendidikan. Namun sebenarnya di dalam tujuan pendidikan nasional sendiri sudah terintegrasi nilai-nilai pendidikan multikultural, hanya saja pelaksanaannya diserahkan kepada sekolah di lokalnya masing-masing ${ }^{14}$

Tawaran tentang pentingnya pendidikan multikultural yang diwacanakan para pakar pendidikan di Indonesia ini dalam batas tertentu mendapat tanggapan yang positif dari pihak eksekutif dan legislatif. Hal ini terbukti dengan diundangkannya Undang-undang Republik Indonesia No. 20 Tahun 2003 tentang Sistem Pendidikan Nasional, yang mengakomodasi nilai-nilai hak asasi manusia dan semangat multikultural. Bahkan nilai-nilai tersebut dijadikan sebagai salah satu prinsip penyelenggaraan pendidikan nasional, sebagaimana yang termaktub pada Bab III pasal 4, ayat 1: "Pendidikan diselenggarakan secara demokratis dan berkeadilan serta tidak diskriminatif dengan menjunjung tinggi hak asasi manusia, nilai keagamaan, nilai kultural, dan kemajemukan bangsa"15

Dalam pendidikan agama, sikap ketaatan kepada Allah sangat ditekankan. Pendidikan agama untuk membentuk pribadi muslim yang

${ }^{13}$ H.A.R. Tilaar. "Multikulturalisme: Tantangan-tantangan Global Masa Depan dalam Transformasi Pendidikan Nasional". Jakarta: Gramedia Indonesia. 2014, Hlm 179

${ }^{14}$ Abdullah Aly. Pendidikan Islam Multikultural di Pondok Pesantren: Telaah terhadap Kurikulum di Pondok Pesantren Modern Islam Assalam Surakarta. Yogyakarta: Pustaka Pelajar, 2011., Hlm. 6-7

${ }^{15}$ Suardi. Pendidikan Multikultural: Sebuah Dekonstruksi Pendidikan diTengah Kemajemukan. dalam jurnal Wahana Didaktika vol. 14 no. 1 januari 2016, Hlm. 19 


\section{Pendidikan Islam Multikultural}

religius. Pribadi muslim merupakan sebuah proses ketundukkan seseorang terhadap seluruh perintah Allah. Dalam al-Qur'an, Allah memerintahkan kepada orang-orang beriman untuk memasuki Islam secara kaffah/keseluruhan. Sebagaimana Firman Allah dalam Surah al-Baqarah [2]: 208: "Wahai orang-orang yang beriman! Masuklah ke dalam Islam secara keseluruhan, dan janganlah kaтu ikuti langkah-langkah setan. Sungguh, ia musuh yang nyata bagimu."

Perpaduan antara multikultural dengan Pendidikan Agama Islam akan bermuara pada upaya penemuan definisi serta tujuan yang sama. Pendidikan Agama Islam multikultural bertujuan menempatkan multikulturalisme sebagai tujuan dari pendidikan itu sendiri dengan karakter yang bersifat inklusif, demokratis dan humanis serta tidak tercerabut dari sesuatu yang sangat fundamental dari agama Islam, yaitu; alQur'an dan as-Sunah (Hasan, 2016: 51). Apabila multikulturalisme sebagai sebuah ide dijadikan tujuan dari Pendidikan Islam, maka kiranya sudah mendesak sekali untuk membumikan pendidikan Islam berwawasan multikulturalisme. Kesadaran akan pentingnya multikulturalisme dipandang menjadi perekat baru integrasi bangsa yang sekian lama tercabik-cabik.

Hal tersebut pada intinya adalah seruan pada semua umat manusia, termasuk mereka para pengikut agama-agama, menuju satu cita-cita bersama kesatuan kemanusiaan (unity of mankind) tanpa membedakan ras, warna kulit, etnik, kebudayaan, dan agama. Pesan kesatuan ini secara tegas disinyalir al-Qur'an: "Katakanlah: Wahai semua penganut agama (dan kebudayaan)! Bergegaslah menuju dialog dan perjumpaan multikultural (kalimatun sawa') antara kami dan kamu”.

Sementara implementasi di lembaga pendidikan, pendidikan Agama multikultural dapat meminimalisir terjadinya pertikaian, perpecahan, maupun peperangan antar agama, ras, suku, maupun bangsa. Contoh praktik penerapannya sebagai berikut: 1). Peserta didik dikenalkan perbedaan budaya, agama, ras, suku, dan bangsa lain. Perbedaan ini sudah sunnatullah agar manusia dapat saling mengenal (al-Hujurat: 13) dan saling 


\section{Zainal Arifin}

menghargai. 2). Peserta didik ditanamkan prasangka-prasangka positif terhadap perbedaan agama, ras, suku, maupun bangsa dan menghindarkan diri dari prasangka-prasangka negatif. 3). Peserta didik ditanamkan sikap simpati, respek, apresiasi, dan empati terhadap penganut agama, budaya, ras, suku, maupun bangsa yang berbeda. 4). Peserta didik ditanamkan sikap positif dan saling menghargai perbedaan ${ }^{16}$ Secara teoretik pembelajaran agama multikultural akan dapat mengembangkan pemahaman dan apresiasi antar etnik yang dimulai dari latar belakang etniknya sendiri dan baru kemudian diperluas kepada etnik lainnya. Melalui pendekatan proses diharapkan dapat membuat kelompok etnik yang berbeda latar belakang sosial dan budaya akan berusaha mengembangkan pemahaman dan rasa hormat terhadap keragaman budaya, memperkecil etnosentrisme.

Penegasan di atas memperkuat sebuah persepsi bahwa pendidikan multikultural mutlak diperlukan untuk membangun karakter suatu bangsa. Melalui pendidikan multikultural sikap saling menghargai saling pengertian dan saling percaya terhadap perbedaan akan terbangun dan berkembang dengan baik. Apalagi ketika faktor-faktor yang menjadi motivasi munculnya konflik konflik di negeri ini dikaitkan dengan karakter bangsa kita yang rentan diprovokasi. Dengan kandungan ketiga muatan nilai-nilai tersebut pendidikan multikultural bisa dikatakan sangat mendesak sebagai sarana yang paling strategis untuk mengasah menanamkan kesadaran dan mengembangkan warga negara yang memiliki gak apa-apa keterampilan menumbuhkan kesadaran akan cara hidup demokratis yang intinya adalah penanan moral serta partisipasi aktif menuju masyarakat madani Indonesia ${ }^{17}$.

Pendidikan Agama dan Pendidikan Multikultural, dalam konteks keIndonesiaan, merupakan tanggung jawab kita bersama sebagai suatu bangsa. Karena agama bisa menjadi pemantik adanya sikap intoleran, maka

\footnotetext{
${ }^{16}$ Zainal Arifin. "Pendidikan Multikultural-Religius untuk Mewujudkan Karakter Peserta Didik yang Humanis-Religius". dalam Jurnal Pendidikan Islam Volume I, Nomor 1, Jun, 2012, Hlm 12

${ }^{17}$ Sulalah. Pendidikan Multikultural, Didaktika Nilai-nilai Universalitas Kebangsaan. Malang: UIN Maliki Press, 2012, Hlm. 66
} 


\section{Pendidikan Islam Multikultural}

segenap umat beragama diharapkan mengambil bagian aktif dalam upaya menggapai idealisme luhur ini. Pola pemahaman agama yang kontekstual, manusiawi dan cerdas, pendekatan dialogis-inklusif-humanis perlu dikembangkan dalam membina hubungan antaragama dan hubungan lintas budaya di Tanah Air kita. Di sinilah pentingnya pendidikan multikultural dalam seluruh tatanan kehidupan kemasyarakatan dan kebangsaan kita. Melalui pendidikan multikultural ini, sikap saling menerima dan menghargai antaretnis, antarumat beragama dan antarbudaya terus kita pupuk dan kita kembangkan dalam mewujudkan kesatuan dalam keragamaan atau keragaman dalam kesatuan dalam kehidupan bermasyarakat, berbangsa dan bernegara di seluruh wilayah Indonesia tercinta ini. Dan apabila ini dapat diwujudkan, korelasi positif nasionalisme, konstitusionalisme dan multikulturalisme akan terus tumbuh dan berkembang subur di Tanah Air kita. Sehingga empat pilar kehidupan bernegara yakni Pancasila, Undang-Undang dasar Negara Republik Indonesia Tahun 1945, NKRI dan Bhineka Tunggal Ika selalu bersinergi. Pancasila adalah falsafah dan dasar negara yang menjadi landasan ideal bangsa Indonesia. UUD 1945 adalah landasan konstitusional yang mendasari penyelenggaraan kehidupan, bermasyarakat, berbangsa dan bernegara. NKRI adalah pemersatu bangsa dan Bhineka Tunggal Ika adalah perekat persatuan dalam untaian kemajemukan ${ }^{18}$

\footnotetext{
${ }^{18}$ Marzukie Ali, 2010. "Pemahaman Multikulturalisme untuk Keutuhan Negara Kesatuan Republik Indonesia”. Surabaya: Makalah dalam Bahan Pembicara untuk Dialog Kebangsaan Universitas Negeri 23 Desember 2010, Hlm. 4
} 


\section{Zainal Arifin}

\section{Daftar Pustaka}

Abdullah Aly, 2011. Pendidikan Islam Multikultural di Pondok Pesantren: Telaah terhadap Kurikulum di Pondok Pesantren Modern Islam Assalam Surakarta. Yogyakarta: Pustaka Pelajar

Ema Erfina, 2017. Pendidikan Islam Multikultural Berbasis Kearifan Lokal: Studi Lokasi Pondok Pesantren Babussalam Mojoagung Jombang dan Pondok Pesantren Mamba'ul Qur'an Mojokerto. Universitas Islam Malang: Disertasi,

H.A.R. Tilaar. 2014. "Multikulturalisme: Tantangan-tantangan Global Masa Depan dalam Transformasi Pendidikan Nasional”. Jakarta: Gramedia Indonesia

James A. Banks \& John Ambrosio. 2001. “Multikultural Education” dalam Handbook of Research on Multikultural Education San Fransisco: Jossey-Bass

Marzukie Ali, 2010. "Pemahaman Multikulturalisme untuk Keutuhan Negara Kesatuan Republik Indonesia”. Surabaya: Makalah dalam Bahan Pembicara untuk Dialog Kebangsaan Universitas Negeri 23 Desember 2010,

Muhammad Qurais Shihab. 2002. Tafsir al-Mishbah: Pesan, Kesan, dan Keserasian Al-quran. Vol XIII Jakarta: Lentera hati

Muhammad Tholhah Hasan, 2016. Pendidikan Multikultural sebagai Opsi Penanggulangan Radikalisme. Malang: Lembaga Penerbitan Universitas Islam Malang

Suardi. Pendidikan Multikultural: Sebuah Dekonstruksi Pendidikan diTengah Kemajemukan. dalam jurnal Wahana Didaktika vol. 14 no. 1 januari 2016

Sulalah, 2012. Pendidikan Multikultural, Didaktika Nilai-nilai Universalitas Kebangsaan. Malang: UIN Maliki Press

Yaqub Cikusin, 2016. Perkembangan Masyarakat Multikultural. Malang: Unisma 


\section{Pendidikan Islam Multikultural}

Yaya Suryana \& H.A Rusdiana. 2015. Pedidikan Multikultural: Suatu Upaya Penguatan Jatidiri Bangsa: Konsep, Prinsip, Implementasi. Bandung: Pustaka Setia

Zainal Arifin. "Pendidikan Multikultural-Religius untuk Mewujudkan Karakter Peserta Didik yang Humanis-Religius”. dalam Jurnal Pendidikan Islam Volume I, Nomor 1, Jun, 2012 